\title{
Modification of Immediate Postplacenta CuT-380A IUD Insertion Using Ring Forceps and Standard Inserter: Twelve Months Follow-up
}

\author{
Modifikasi Teknik Insersi IUD CuT-380A Pascaplasenta Menggunakan \\ Ring Forceps dan Inserter Standar: Pemantauan Dua Belas Bulan
}

\author{
Hary Tjahjanto, Wijoyo Hadiningrat \\ Department of Obstetrics and Gynecology \\ Faculty of Medicine University Diponegoro/ \\ Dr. Kariadi Hospital \\ Semarang
}

\begin{abstract}
Objective: To evaluate the outcome of CuT-380A IUD postplacental insertion in vaginal delivery using new modification insertion technique.

Method: We carried out a prospective cohort study of postplacental IUD insertion by means of 'push and push' technique, using ring forceps and standard inserter (inserter tube and plunger rod). We included women who underwent vaginal delivery from 1st June 2009 until 31st March 2011 and had postplacental IUD insertion. Followup was conducted for 12 months, including history, physical examination, ultrasound and questionnaires during evaluation, through home visits and by phone. The first monitoring is before 6 weeks after delivery, the second monitoring was after 6 weeks up to 3 months, the third is after 3 months up to 6 months, the fourth is after 6 months up to 12 months, the fifth is after 12 months up to 24 months and the sixth is after 24 months up to 32 months after insertion.
\end{abstract}

Result: On the second monitoring, 2 acceptors experienced expulsion. At the third monitoring period, one acceptor requested for IUD removal. At 9 months up to 12 months post-insertion, one expulsion was encountered, and one acceptor requested removal of device. At $\geq 12$ months there was one acceptor who had IUD removal. We did not find any report of unintended pregnancy or perforation.

Conclusion: Immediate post-placental insertion of CuT-380A IUD after vaginal delivery using 'push and push' technique is safe and effective. The pregnancy rate at typical use is $0 \%$, continuation rate is $94.1 \%$ and low expulsion rate $(2.86 \%)$. Loss of follow up was $5.6 \%$ and no perforation was reported.

[Indones J Obstet Gynecol 2015; 2: 85-93]

Keywords: continuation rate, immediate post-placental IUD insertion, 'push and push' technique, typical use, vaginal delivery

\begin{abstract}
Abstrak
Tujuan: Mempelajari luaran insersi IUD CuT-380A pascaplasenta persalinan pervaginam menggunakan teknik modifikasi baru 'push and push'.

Metode: Kami melaksanakan studi kohort prospektif, sampel adalah semua ibu yang menjalani persalinan pervaginam pada 1 Juni 2009 sampai dengan 31 Maret 2011. Pemantauan dilakukan selama 12 bulan, yang meliputi anamnesis, pemeriksaan fisik, USG dan kuesioner saat kontrol, yang dilakukan melalui kunjungan rumah dan melalui telepon. Pemantauan dilakukan pada periode $<6$ minggu setelah persalinan, 6 minggu s/d 3 bulan, 3 bulan s/d 6 bulan, 6 bulan s/d 9 bulan, 9 s/d 12 bulan; dan lebih dari 12 bulan pascapersalinan.

Hasil: Pada pemantauan periode 6 minggu sampai dengan 3 bulan pascapersalinan terdapat 2 akseptor yang mengalami ekspulsi. Pada pemantauan periode 3 bulan sampai dengan 6 bulan terdapat 1 akseptor yang meminta pencabutan IUD. Pada pemantauan periode 9 bulan sampai dengan 12 bulan, terdapat 1 kejadian ekspulsi dan 1 pencabutan IUD. Pada pemantauan setelah 12 bulan terdapat 1 pencabutan IUD. Tidak ada laporan kejadian perforasi maupun kehamilan.
\end{abstract}

Kesimpulan: Insersi IUD pascaplasenta menggunakan teknik 'push and push' ditemukan aman dan efektif. Kehamilan pada penggunaan tipikal 0\%, angka kelangsungan tinggi $(94,1 \%)$ dan angka ekspulsi rendah $(2,86 \%)$. Loss to follow up sebanyak $5,6 \%$ dan tidak ditemukan kejadian perforasi.

[Maj Obstet Ginekol Indones 2015; 2: 85-93]

Kata kunci: angka kelangsungan, IUD pascaplasenta, penggunaan tipikal, persalinan pervaginam, teknik 'push and push'

Correspondence: Hary Tjahjanto, Muradi street no. 30, Semarang, Indonesia 50145. Phone: +628122810945 , E-mail : hary_tj@yahoo.com

\section{INTRODUCTION}

Postpartum IUD insertion was first performed by Liss and Andros (1963). Insertion was performed at 2-8 days postpartum, mostly on day four postpartum. Insertion technique utilizes a vaginal speculum, tenaculum and special inserter. The next year, Burnhill and Birnberg introduced Birnberg's bow insertion immediately after placenta delivery by using two fingers without use of a special inserter. In 1966, The International Postpartum Family Planning Program of the Population Council initiated a multicentre study where IUD insertion was performed before patients were discharged from the hospital, usually within 10 days after de- 
livery. Overall expulsion rate of 20.5 per 100 women was obtained at 3 months follow-up. Expulsion rate was in the range of $7.35 \%$ to $46.2 \%{ }^{1}$

Sutopo et al performed insertion using type D and C Lippes Loop IUD at seven days postpartum, mostly on the first and second day of postpartum. Insertion was performed without a vaginal speculum, instead utilizing the index finger inserted into the cervical canal and the middle finger in the posterior or lateral fornix to immobilize the cervix. IUD was inserted using a special inserter (length $30 \mathrm{~cm}$, diameter $5 \mathrm{~mm}$ ). Among the 1,945 women, the expulsion rate was $10.8 \%$. Highest expulsion incidence occurred in the first 3 months after insertion (7.7\%), whereas at 3-6 months post-insertion the rate of expulsion was $1.5 \%{ }^{2}$

Sitompul et al demonstrated ML-Cu250 IUD insertion by holding the device between the index and middle finger, placed as high as possible in the uterine cavity, immediately inserted after delivery of the placenta. Results of 3 months monitoring showed expulsion rate was $7.1 \%$ from the 75 acceptors with loss of follow-up rate being $40 \%{ }^{3}$

Timing of IUD insertion can be classified as immediately or less than 10 minutes after delivery of the placenta (immediate postplacental insertion or IPPI), 48 hours postpartum (immediate postpartum), 4-8 weeks postpartum (late postpartum insertion) and interval insertion. Interval insertion is still widely chosen because of the low expulsion rate $(3-13 \%)$ in comparison to IPPI (9.5 to $12.5 \%$ ) and IPP (25-37\%). Late postpartum insertion is not recommended due to the high rates of expulsion and perforation. ${ }^{1,4,5}$ Nevertheless, postpartum insertion, especially immediate postplacental insertion, is superior to the interval insertion since it can reach acceptors as soon as possible since they already have had the device inserted when leaving the health facility, causes the patient very minimal pain because the cervix is still widely dilated, and is less expensive. ${ }^{4,5}$

In accordance with the practical guideline in normal birth management, active management of third stage of labor includes intramuscular injection of one ampoule oxytocin within the first minute after the baby is delivered in order to produce uterine muscle contraction immediately, preventing postpartum bleeding and reducing blood loss. ${ }^{6}$ When applying this guideline, IUD insertion immediately after delivery of the placenta using the fingers tend to be difficult due to onset of myometrial contractions soon after the baby is born. Inserting the fingers and palm of the hand into the uterine cavity can prove to be hard and very uncomfortable for the mother. ${ }^{7}$ To reduce the incidence of expulsion, in addition to IUD insertion training and clinical experiences in inserting IUD, it is important to place the IUD as high as possible in the fundus (high fundal placement). ${ }^{1,5,8}$

A postplacental IUD insertion method introduced by Hary Tjahjanto called the 'push and push' technique has been implemented in Kariadi Hospital since June 2009. This technique is a new modification of the existing postplacental IUD insertion technique, using a combination of ring forceps and standard inserter (standard inserter tube and plunger rods), so that the IUD can actually be placed in the middle of the uterine fundus although the cervical canal has been narrowed due to uterine contractions. ${ }^{7}$

\section{METHODS}

This study was conducted at Kariadi Hospital, a tertiary referral and teaching hospital for obstetrics and gynecology in Central Java. Our study was conducted prospectively, including all women who underwent vaginal delivery during the period of $1^{\text {st }}$ June 2009 to $31^{\text {st }}$ March 2011 that met the inclusion criteria, agreed to have immediate postplacental CuT-380A IUD insertion, and completed 12 months of monitoring. Inclusion criteria include all women who underwent vaginal delivery (spontaneous, with vacuum extraction or manual aid) who were willing to come to the clinic and undergo ultrasound monitoring according to the specified monitoring schedule. Whereas, exclusion criteria were women with sexually transmitted diseases/ AIDS, gynecologic malignancy, uterine anatomic abnormalities and women who do not require immediate contraceptives, including those with primary infertility, stillbirth or IUFD.

\section{Insertion Method}

IUD insertion was performed by the researchers and trained residents. The IUD string was cut at approximately $6 \mathrm{~cm}$ from the end of the vertical stem or in the middle of a long string. Afterwards, the string and vertical stem is inserted into the IUD inserter, but the horizontal arm remains outside the tube inserter. The plunger rod is inserted into the inserter tube and the inserter tube is clamped 
with the horizontal arm in line with the tip of the ring forceps, or slightly lower than the outer edge of ring forceps tip (See figure 1). After the index and middle fingers enters the vagina, both ends of the fingers should be advanced through the lower uterine segment to reach the fibromuscular junction of the uterine corpus. Using the left hand to hold the ring forceps, the ring forceps is inserted gradually guided by the palm of the hand, onwards between the index and middle finger of the right hand until reaching the fibromuscular junction. After the ring forceps has been advanced maximally into the uterine cavity, the ring forceps is maintained in position using the first, fourth and fifth fingers of the right hand (See figure 2) while pressing the fundus using the left hand, so that the tip of the ring forceps slightly moves forward in the uterine cavity. The left hand is then used to push the ring forceps further into the uterine cavity, while the fingers of the right hand directs and maintains the position of the ring forceps. The left hand then presses the fundus again, advancing the ring forceps further into the uterine cavity. The process is repeated until the end of the ring forceps reached the fundus and the pressure is felt by the left hand upon palpation of the uterine fundus through the abdominal wall. Afterwards, with the left hand holding the inserter, the ring forceps is opened for 1-2 cm using the right hand, and the inserter tube is pushed to allow the tip of the ring forceps to be more attached to the wall of the uterine fundus. While maintaining inserter position using the left hand, ring forceps is removed and the inserter tube is pushed again so that the inserter tip moves into the narrow gap between the anterior and posterior uterine fundus wall, in conjunction with fundus control using the left hand. With the plunger rod held by the right hand, the inserter tube is withdrawn so the proximal end of the tube touches the ring of the plunger rod. Then the plunger rod is pulled out of the inserter tube, followed by pulling out the inserter tube from the uterine cavity. Thus, in addition to the ring forceps gradually entering the uterine cavity, insertion is done by pushing the ring forceps and standard inserter three times to place the IUD right in the center of the uterine fundus. Firstly when the ring forceps and inserter is inserted into the uterine cavity and later gradually driven to reach the fundus. Then, when the ring forceps was opened, the inserter is encouraged to move in the gap of the fundus wall; and after the ring forceps are removed from the uterine cavity, the inserter is advanced further so that the tip of the ring forceps is more attached to the walls of the uterine fundus. Advancement of the ring forceps or tube inserter must be accompanied by fundus palpation on the abdominal wall with the left hand to ensure the position of the ring forceps tip right in the centre of the fundus and to prevent perforation.

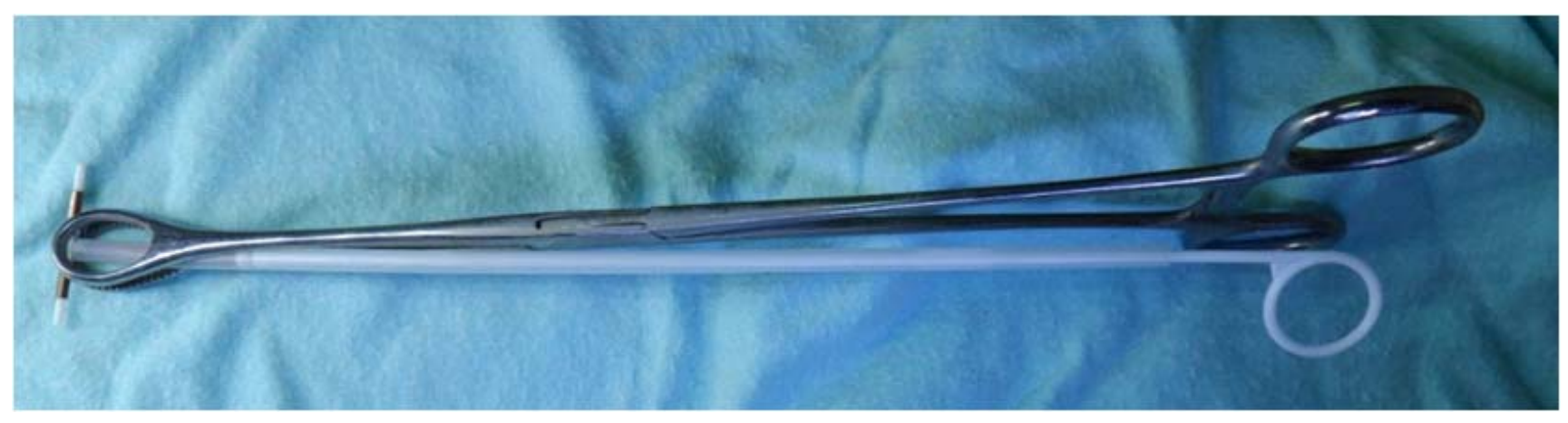

Figure 1. How to Place the IUD in the Inserter Tube and Clamped with the Ring Forceps. 


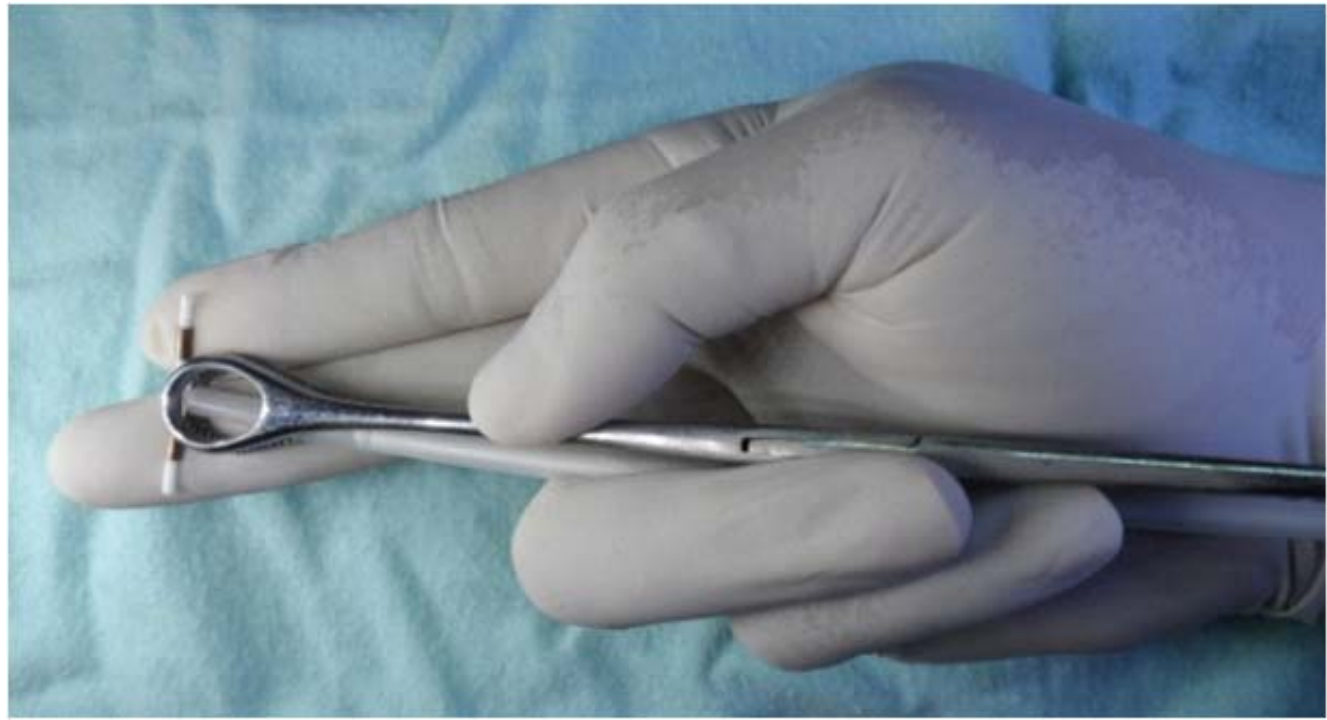

Figure 2. How to Use the First, Fourth and Fifth Fingers of the Right Hand to Hold the Ring Forceps.

IUD insertion was not limited to the first $10 \mathrm{~min}$ utes after delivery of the placenta. Insertion is done when the uterine cavity has been confirmed to be clean of blood clots and any amniotic tissue. This is done to reduce the risk of expulsion, especially during puerperal period. In addition to requiring the uterine cavity to be in a clean state, uterine tonic contractions is also needed to reduce the risk of expulsion by administering intramuscular injection of one ampoule of oxytocin after the baby is born. If no contraindications were present, methylergometrine maleate was also given through intramuscular or intravenous injection during or after delivery of the placenta. In women with weak uterine contractions or at risk for weak uterine contraction in the third stage of labor; for example women who were multigravida, or had severe preeclampsia or typhoid fever or hepatitis; $600-800 \mu \mathrm{g}$ of misoprostol was administered per rectal as additional uterotonic agents. Furthermore, to ensure maintenance of uterine involution, methylergometrine maleate tablets were administered ( $1 / 2-1$ tablet, three times daily for 1-2 weeks).

\section{Follow-up Schedule}

At the first follow-up visit, within 6 weeks postpartum, routine gynecological examination was performed to assess the presence of excessive bleeding complications, partial or complete expulsion, and perforation through pelvic examination. Transvagi- nal or abdominal ultrasonography of the pelvis was performed to determine the position of the IUD. At the second ( 6 weeks up to 3 months postpartum), third ( 3 up to 6 months postpartum), fourth (6 up to 9 months postpartum), fifth ( 9 up to 12 months postpartum) and sixth (more than 12 months) monitoring visits, abdominal ultrasound examination was performed and IUD string was cut when necessary. Furthermore, presence of side effects and continuation of IUD use was evaluated. When acceptor did not present within the predetermined schedule, interview by phone, written letter or home visit was performed. If the patient could not be contacted until the end of the study, they were considered lost to follow-up.

The parameters studied were efficacy, incidence of complications related to IUD use and continuation rate. Data were recorded in a special form and analyzed descriptively.

\section{RESULTS}

From $1^{\text {st }}$ June 2009 until 31 $1^{\text {st }}$ March 2011, 431 postplacenta IUD insertions were carried out. At the end of the study, the number of women who were observed and have been using an IUD for 12 months or more was 108 mothers. The number of acceptors that can be monitored for 12 months is 102 acceptors of IUD acceptors. Thus, lost to follow-up is $5.6 \%$. 
Vol 3, No 2

April 2015

Table 1. Monitoring Data

\begin{tabular}{lcccccc} 
& M-1 & M- 2 & M-3 & M-4 & M-5 & M-6 \\
\hline Acceptor & 108 & 108 & 108 & 108 & 108 & 108 \\
Observation & & & & & & \\
$\quad$ Visit & $23(21.3 \%)$ & $18(16.7 \%)$ & $4(3.7 \%)$ & $2(1.8 \%)$ & $9(8.4 \%)$ & $26(24.1 \%)$ \\
$\quad$ By phone & $29(26.8 \%)$ & $25(23.1 \%)$ & $36(33.3 \%)$ & $8(7.4 \%)$ & $15(13.8 \%)$ & $76(70.3 \%)$ \\
Total observed & $52(4.1 \%)$ & $43(39.8 \%)$ & $40(37.0 \%)$ & $10(9.2 \%)$ & $24(22.2 \%)$ & $102(94.4 \%)$ \\
Loss to follow-up & $56(51.9 \%)$ & $65(60.2 \%)$ & $68(63.0 \%)$ & $98(90.8 \%)$ & $84(77.8 \%)$ & $6(5.6 \%)$ \\
\hline \hline
\end{tabular}

Note: $M-1=$ up to 6 weeks postpartum, $M-2=6$ weeks up to 3 months postpartum, $M-3=3$ up to 6 months postpartum, $M-4=6$ up to 9 months postpartum, $M-5=9$ up to 12 months postpartum, $M-6=12$ months postpartum or later.

The most commonly encountered age group amoung the acceptors was 30-34 years old (27.1\%), with the youngest being 17 years old and the oldest being 42 years old. The proportion of preterm delivery was only $6.7 \%$, while the rest were full-term and post-term deliveries (93.4\%). The proportion of primipara and multipara was al- most equal. The average body mass index was 19.92. Almost all of the babies' birth weight was in the range of 2,500-3,999 grams. Three-quarters of the deliveries were spontaneous labor. As many as 15 acceptors (13.9\%) had premature rupture of membranes at the time of delivery (Table 2).

Table 2. Patient Characteristics

\begin{tabular}{|c|c|c|c|c|c|}
\hline Variable & $\mathbf{n}$ & Proportion (\%) & Mean (SD) & Min & Max \\
\hline Age (years) & & & 27.41 & 17 & 42 \\
\hline $15-19$ & 10 & 9.3 & & & \\
\hline $20-24$ & 28 & 26.2 & & & \\
\hline $25-29$ & 28 & 26.2 & & & \\
\hline $30-34$ & 29 & 27.1 & & & \\
\hline$\geq 35$ & 12 & 11.2 & & & \\
\hline Normotension & 92 & & 119.95 (7.129) & 100 & 130 \\
\hline Hypertension & & & $157.14(13.828)$ & 140 & 180 \\
\hline $140-160 \mathrm{mmHg}$ & 11 & 10.2 & & & \\
\hline$>160 \mathrm{mmHg}$ & 3 & 2.8 & & & \\
\hline $\mathrm{BMI}^{*}$ ) & 85 & & $25.93(3.40)$ & 19.92 & 39.54 \\
\hline Gestational age (weeks) & & & 38.74 (1.95) & 30 & 42 \\
\hline Preterm & 7 & 6.6 & & & \\
\hline Full term & 95 & 90.5 & & & \\
\hline Post-term & 3 & 2.9 & & & \\
\hline Parity & & & $1.69(0.79)$ & 1 & 4 \\
\hline Primipara & 52 & 48.6 & & & \\
\hline Multipara & 55 & 51.4 & & & \\
\hline \multicolumn{6}{|l|}{ PROM } \\
\hline No & 93 & 86.1 & & & \\
\hline Yes, $<6$ hours & 10 & 9.3 & & & \\
\hline Yes, $>6$ hours & 5 & 4.6 & & & \\
\hline
\end{tabular}




\begin{tabular}{lccccc}
\hline \hline \multicolumn{1}{c}{ Variable } & n & Proportion (\%) & Mean (SD) & Min & Max \\
\hline $\begin{array}{l}\text { Birth weight (gr) } \\
<2500\end{array}$ & 7 & & $2,995(382)$ & 1,800 & 4,250 \\
$2500-3999$ & 100 & 6.5 & & & \\
$\quad>4000$ & 1 & 92.6 & & \\
Mode of delivery & & 0.9 & & \\
$\quad$ Spontaneous & 81 & 75 & & \\
$\quad$ Vacuum extraction & 25 & 23.1 & & \\
Breech delivery & 2 & 1.9 & & \\
Haemoglobin (g\%) & & & & \\
$<8$ & 2 & 2.1 & & \\
$8-10$ & 15 & $15.06(1.31)$ & & \\
$10-12$ & 53 & 55.2 & & \\
$\geq 12$ & 26 & 27.1 & & \\
\hline \hline
\end{tabular}

$B M I=$ Body Mass Index, PROM = premature rupture of the membrane *) $n=$ number of samples for which data is complete

As many as 52 acceptors were observed on the first monitoring with no complaint of smelly lochia, but 5.8\% reported having experienced a period of fever after childbirth. Complaints of vaginal dis- charge, pelvic pain, painful menstruation, and excessive menstrual blood were also reported by some acceptors but did not lead to request for IUD removal (Table 3).

Table 3. Patient Complaints at Each Monitoring Period.

\begin{tabular}{|c|c|c|c|c|c|c|}
\hline & $M-1(n=52)(\%)$ & $M-2(n=43)(\%)$ & $M-3(n=40)(\%)$ & $M-4(n=10)(\%)$ & $M-5(n=24)(\%)$ & M-6 (n=102) (\%) \\
\hline \multicolumn{7}{|l|}{ Smelly lochia } \\
\hline - No & $52(100)$ & & & & & \\
\hline - Yes & -- & & & & & \\
\hline \multicolumn{7}{|l|}{ Vaginal discharge } \\
\hline - No & & $30(69.8)$ & 37 (92.5) & $7(70)$ & $23(95.8)$ & $81(79.4)$ \\
\hline - Yes & & $13(30.2)$ & $3(7.5)$ & $3(30)$ & $1(4.2)$ & $21(20.6)$ \\
\hline \multicolumn{7}{|l|}{ Puerperal fever } \\
\hline - No & $49(94.2)$ & & & & & \\
\hline - Yes & $3(5.8)$ & & & & & \\
\hline \multicolumn{7}{|l|}{ Pelvic discomfort } \\
\hline - No & $52(48.1)$ & $42(97.7)$ & $40(100)$ & $10(100)$ & $24(100)$ & 93 (91.2) \\
\hline - Yes & $56(51.9)$ & $1(2.3)$ & -- & -- & -- & $9(8.8)$ \\
\hline \multicolumn{7}{|l|}{ Dysmenorrhea } \\
\hline - No & & $10(83.3)$ & $39(97.5)$ & 7 (77.8) & 17 (73.9) & $55(53.9)$ \\
\hline - Yes & & $2(16.7)$ & $1(2.5)$ & $2(22.2)$ & $6(26.1)$ & $47(46.1)$ \\
\hline \multicolumn{7}{|c|}{ Menstrual bleeding } \\
\hline - Normal & & $12(100)$ & $40(100)$ & $9(100)$ & $22(95.7)$ & $100(98.0)$ \\
\hline - Menorrhagia & & -- & -- & -- & $1(4.3)$ & $2(2.0)$ \\
\hline
\end{tabular}


Table 4. Timetable of Expulsion, IUD Removal and Cummulative Continuation Rate (n=102).

\begin{tabular}{lcccccc}
\hline \hline & M-1 & M-2 & M-3 & M-4 & M-5 & M-6 \\
\hline Expulsion & 0 & $2(1.96 \%)$ & $2(1.96 \%)$ & $2(1.96 \%)$ & $3(2.86 \%)$ & $3(2.86 \%)$ \\
Removal & & & & & & \\
- medical & 0 & 0 & $1(0.98 \%)$ & $1(0.98 \%)$ & $1(0.98 \%)$ & $2(1.96 \%)$ \\
- pregnancy & 0 & 0 & 0 & 0 & 0 & 0 \\
- personal & 0 & 0 & 0 & 0 & $1(0.98 \%)$ & $1(0.98 \%)$ \\
Continuation rate & $102(100 \%)$ & $100(98.04 \%)$ & $99(97.06 \%)$ & $99(97.06 \%)$ & $97(95.09 \%)$ & \\
\hline \hline
\end{tabular}

At the final follow-up visit (more than 12 months) $94.4 \%$ of acceptors were observed. Cummulatively, we encountered three occurences of IUD expulsion (2.86\%) and three removals (2.94\%), two were removed due to medical reasons $(1.96 \%)$ and one acceptor $(0.98 \%)$ cited personal reasons. Thus, the continuation rate was $94.2 \%$.

\section{DISCUSSION}

A major problem in postplacental IUD insertion is the high expulsion rate in comparison to interval insertion. High rates of expulsion is influenced by timing of insertion and the method of IUD insertion. 8,9 A cohort study by Stumpf and Lenker involving 114 women, using modified Lippes Loop IUD found that at 6 months post-insertion expulsion rate was 30\%; and compared to ring forceps insertion; most expulsions occurred in the digital insertion group. They concluded that the modified form of IUDs does not influence the risk for expulsion, but it is instead affected by the IUD insertion technique. $^{8}$

A Cochrane review in 2010 included a multicentre study by WHO involving 841 women as samples. Comparison of the Nova-T-PP, Lippes Loop D, and Copper 7, indicated that the Lippes Loop was likely to be inferior to the other two devices. The 12-month discontinuation rates due to expulsion per 100 women were 41.3 for the Nova-T-PP, 44.1 for the Lippes Loop, and 34.8 for the Copper 7. The corresponding 12-month pregnancy rates showed that Lippes Loop had the highest pregnancy rate with 12.1 per 100 women. Total 12 -month discontinuation rates were high with all devices; 53.1, 60.9, and 47.7 per 100 women for Nova-T-PP, Lippes Loop D, and Copper 7, respectively. The discontinuation rate at 12 months was significantly higher for the Lippes Loop than for the Copper 7. A study by Thiery et al included 562 women re- ceiving either TCu-200 or MLCu-250 IUDs, who were observed for 12 months. Expulsion rates were $9.9 \%$ and $11.2 \%$ and pregnancy rates were $2.4 \%$ and $0.5 \%$, respectively. Lavin et al observed 400 women receiving Progestasert IUD or TCu-200 IUD for 12 months. Expulsion rates were 35.8\% and $9.0 \%$ with hand insertions, and $35.2 \%$ and $8.1 \%$ with ring forceps insertion, respectively. A multicenter study by Family Health International study included a total subject of 3,797 women from 13 countries. Expulsion rate of Delta Loop IUD inserted by hand or using ring forceps were comparable $\%$ at 6 months monitoring. ${ }^{9}$

Apello et al observed 400 women for 12 months. Expulsion rate of TCu-200 IUD and Progestasert by hand insertion were $19.9 \%$ and $39.0 \%$, respectively. While insertion using instruments found expulsion rate to be $10.3 \%$ and $14.2 \%$, respectively. Kisnisci et al discovered expulsion rate of Delta-T IUD was $7.6 \%$ and $3.7 \%$ for Delta Loop, but the insertion method was not mentioned. 9,10

Van Kets et al included 408 women with an 18months monitoring period; and found that expulsion rates for postpartum Nova-T (Nova-T-PP) and Nova-T were $6.2 \%$ and $6.6 \%$, respectively. Continuation rate at 12 months of Nova-T-PP and Nova-T were $67.2 \%$ and $70.2 \%$, respectively; and pregnancy rates were $0.6 \%$ and $0 \%$ respectively. This indicates that expulsion rate between the two IUD models did not differ significantly, suggesting that the addition of two extra arms to the original Nova$\mathrm{T}$ model does not improve the retention of the adapted IUD model. ${ }^{11}$

$\mathrm{Xu}$ et al observed 910 women using CuT-380A IUD through a 12-months follow-up period, and discovered that the expulsion rate was comparable between hand insertion and insertion using instrument. ${ }^{12}$ Chen et al compared immediate and delayed (post-puerperal) insertion of LNG-IUS, and 
obtained expulsion rates of $23.5 \%$ and $13.7 \%$ at 6 months monitoring, respectively. ${ }^{13}$

We identified two postpartum IUD insertion studies in Indonesia. Soetopo et al studied LL type C and D IUD Insertion performed on day one or two post-partum, and obtained an expulsion rate of $10.8 \% .^{2}$ Meanwhile, Sitompul et al observed digital insertion of MLCu250 IUDs. At 3 months monitoring, the expulsion rate was $7.1 \%{ }^{3}$

Kariadi Hospital applied the 'push and push' technique and obtained expulsion rate of $2.86 \%$ during 12-months follow-up. This technique uses ring forceps and standard IUD inserter (tube inserter and plunger rod). Insertion is performed using a blind method, without use of a vaginal speculum. Using the middle and index finger as a guide to reach the uterine cavity, and by using ring forceps to enter the cervical canal more easily, we were able to place the IUD at the center of the uterine fundal wall. A standard inserter can aid in inserting the IUD as close as possible to the fundal wall and prevent the occurrence of position changes when the ring forceps was pulled out of the uterine cavity. Insertion time is not limited to the first 10 minutes after placenta delivery but it was more preferable to have the uterine cavity to be clean of blood clots and amniotic tissue. By using ring forceps to clamp the inserter tube, the inserter tube can be advanced through the internal cervical os, although the internal cervical os has narrowed. After the ring forceps reaches the fibromuscular junction, it is then gradually pushed into the uterine cavity.

Prospective cohort study by Morrison et al, 1996, in Mali $(n=224)$ and Kenya $(n=110)$, during 6 months monitoring, performed immediate CuT380A IUD insertion and late insertion by hand and ring forceps. In Kenya, 71\% had immediate insertions and $80 \%$ of the insertions were made using ring forceps. In Mali, 54\% of acceptors had immediate insertions and $57 \%$ of insertions were performed by hand. Only four expulsions occurred among the 219 participants completing a follow-up visit in Kenya (1.8\%). In Mali, 19 expulsions (including 15 displacements) occurred among the 98 participants with complete follow-up information $(19.4 \%) .{ }^{14}$

A non-randomized clinical trial by Eroglu et al involved 268 women who had vaginal or cesarean delivery in whom CuT-380A IUD insertion were performed either immediately postplacenta (IPP; up to 10 minutes postpartum), during early postpartum (EP; more than 10 minutes but less than 72 hours after delivery), during the interval period (INT; more than 6 weeks after vaginal delivery or more than 8 weeks after cesarean section. At 1 year follow up, complete expulsion occurred in $14.3 \%$ of the women in the IPP group, in $18.6 \%$ of the EP group, and in $3.8 \%$ of the INT group. Partial expulsion was encountered in $22.6 \%$ of the women in the IPP group, in $51.2 \%$ of the EP group, and in $3.1 \%$ of the INT group. There was a statistically significant difference in regards to the occurrence of complete or partial expulsion based on the time of IUD insertion $(\mathrm{p}<0.001){ }^{15}$

A Cochrane review in 2010 stated that the immediate post-placental insertion (IPPI) is generally safe and effective, with expulsion in IPPI higher than delayed insertion. It also found that modified forms of IUD does not improve the expulsion rates. Moreover, digital insertion and insertion using instrument had similar success, with experience found to be an important factor in reducing expulsion. ${ }^{9,16}$

Celen et al conducted a prospective cohort study assessing the effectiveness of postplacental CuT380A IUD insertion using a ring forceps in vaginal and cesarean deliveries. They obtained an expulsion rate of $12.3 \%$ and 2 pregnancies occurring among the 235 acceptors within 1 year of IUD use $(0.7 \%) .{ }^{17}$

An RCT by Beltagy et al observed the insertion CuT-380A and MLCu-375 IUD within 48 hours after a normal delivery using Kelly forceps, with each group comprised of 150 women. Evaluation included ultrasound examination at 6 weeks and 6 months post-insertion. The expulsion rates for both groups were comparable $(14.9 \%$ for CuT-380A vs $15 \%$ for MLCu-375). A relationship was identified between the distance of the IUD to the endometrium and the occurrence of expulsion, with the cut-off point of $10 \mathrm{~mm} .{ }^{18}$

Several studies stated that there was no incidence of perforation with IPPI., ${ }^{9,14,15}$ In our study, there was no incidence of perforation. To prevent perforation, it is essential that the left hand controls the uterine fundus during each time the ring forceps or inserter are advanced into the fundus. 


\section{CONCLUSION}

In 12 months follow up, there is no occurrence of pregnancy in all 102 acceptors and the number of women who are still using the IUD total of 96 women. So the Pearl index was 0 , or $0 \%$ typical use, and the continuation rate is $94.2 \%$. Expulsion rate by $2.86 \%$ and no incidence of perforation. Thereby can be concluded that immediate postplacental IUD insertion using push and push technique is safe, convenient and high effectiveness.

\section{REFERENCES}

1. Chi I, Farr G. Postpartum IUD contraception: a review of an international experience. Adv Contracept 1989; 5: 127-46.

2. Sutopo. Insersi Dini IUD. Thesis. Fakultas Kedokteran Universitas Indonesia; 1972.

3. Sitompul ER. Penerimaaan dan daya guna IUD MLCu 250 pascaplasenta, hasil observasi jangka pendek. Tesis. Program Studi Obstetri Ginekologi FKUI. 1994.

4. World Health Organization. Medical eligibility criteria for contraceptive use update. A WHO family planning cornerstone. Geneva: World Health Organization; 2008: 1-3.

5. O'Hanley K, Huber DH. Postpartum IUDs: keys for success. Contraception 1992; 45(4): 351-61.

6. JNPK-KR-Depkes. Pelatihan klinik asuhan persalinan normal: asuhan esensial, pencegahan dan penanggulangan segera efek samping persalinan dan bayi baru lahir (Buku Acuan). Jakarta: Jaringan Nasional Pelatihan Klinik-Kesehatan Reproduksi, Departemen Kesehatan RI; 2008: 95187.

7. Tjahjanto H. RSUP Dr. Kariadi dalam mendukung revitalisasi PKBRS. In: PERSI-IHMA Awards, Agustus 2009.

8. Stumpf PG, Lenker RM. Insertion technique, not design, affects expulsion rates of postpartum intrauterine device. Contraception 1984; 30(4): 327-30.
9. Grimes DA, Lopez LM, Schulz KF, et al. Immediate post-partum insertion of intrauterine devices. Cochrane Database Syst Rev 2010; 12(5): CD003036.

10. Apelo RA, Ramos RM, Bernardo E, et al. A 3-year evaluation of the TCu380Ag and the Cu-7. Int J Gynaecol Obstet 1989; 28(3): 269-73.

11. Van Kets H, Thiery M, Van Der Pas H, et al. Immediate postpartum insertion: performance of the Nova-T-PP and randomized comparison with the Nova-T. Adv Contracept 1987; 3: 63-9.

12. Xu J-X, Rivera R, Dunson TR, et al. A comparative study of two twchniques used in immediate postplacental insertion (IPPI) of the copper T-380A in Shanghai, People's Republic of China. Contraception 1996; 54: 33-8.

13. Chen BA, Hayes JL, Hohmann HL, et al. A randomized trial of postplacental compared to delayed insertion of the levonorgestrel-releasing intrauterine device after vaginal delivery. Contraception 2009; 80(2): 194-226.

14. Morrison C, Waszak C, Katz K, e al. Clinical outcomes of two early postpartum IUD insertion programs in Africa. Contraception 1996; 53: 17-21.

15. Eroglu K, Akkuzu G, Vural G, et al. Comparison of efficacy and complications of insertion in immediate postplacental/early postpartum period with interval period: 1 year follow up. Contraception 2006; 74(5): 376-81.

16. Xu J, Reusche C, Burdan A. Immediate postplacental insertion of the intrauterine device: A review of Chinese and the world's experience. Contraception 1996; 54: 33-8.

17. Celen S, Moroy P, Sucak A, et al. Clinical outcomes of early postplacental insertion of intrauterine contraceptive devices. Contraception 2004; 69: 279-82.

18. El Beltagy NS, Darwish EA, Kasem MS, et al. Comparison between Cupper T380 IUD and Multiload 375 IUD in early post partum insertion. Middle East Fertil Society J 2011; 16: 143-8. 